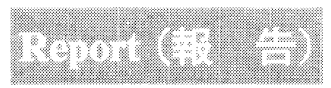

\title{
A Case of Brood Parasitism of Olive-backed Pipits Anthus hodgsoni by the Horsfield's Hawk Cuckoo Cuculus fugax
}

\author{
Gen Morimoto*, Keita Tanaka* and Keisuke Ueda*
}

\begin{abstract}
We report a case of brood parasitism to the Olive-backed Pipit Anthus hodgsoni by the Horsfield's Hawk Cuckoo Cuculus fugax on Mount Fuji in Japan. The hawk cuckoo lays its eggs, mainly in the nests of the Blue-and-white Flycatcher Cyanoptila cyanomelana, Siberian Blue Robin Luscinia cyane and Red-flanked Bushrobin Tarsiger cyanurus. There has been only one clear report that the Olive-backed Pipit was parasitized by the hawk-cuckoo. Our report is a presumable second case.
\end{abstract}

Key words: Brood parasitism, Horsfield's Hawk Cuckoo Cuculus fugax, Olivebacked Pipit Anthus hodgsoni.

キーワード：托卵, ジュウイチ Cuculus fugax, ビンズイ Anthus hodgsoni.

The Horsfield's Hawk Cuckoo Cuculus fugax is the most mysterious cuckoo of the four large cuckoos breeding in Japan (Committee for Check-List of Japanese Birds 2000). There is little information on the breeding ecology and parasitic behaviour of the hawk-cuckoo, because of its low density and inconspicuous behaviour in dense forest. The hawk-cuckoo arrives in Japan in early May and stays until late August for breeding. It lays pale blue-coloured eggs, mainly in the nests of the Blue-and-white Flycatcher Cyanoptila cyanomelana, Siberian Blue Robin Luscinia cyane and Red-flanked Bushrobin Tarsiger cyanurus (Higuchi 1998).

Except for those involving the above "blue birds", records of brood parasitism by the hawk-cuckoo are few. Yamashina (1941), however, listed other six host species that do not have blue plumage: the Olive-backed Pipit Anthus hodgsoni, Brown Flycatcher Muscicapa dauurica, Narcissus Flycatcher Ficedula narcissina, Grey Thrush Turdus cardis, Brown Thrush T. chrysolaus and Stonechat Saxicola torquata. The description of brood parasitism of the Olive-backed Pipit in the list might be an anecdotal data from Keisuke Kobayashi. Kobayashi found a parasitized nest of the pipit at $900 \mathrm{~m}$ asl. on Mount Fuji in 1929 (Kobayashi 1998). Here we report the presumable second known case of brood parasitism of Olive-backed Pipits by the hawk-cuckoo on Mount Fuji.

We conducted a study of hosts of the hawk-cuckoo at Mount Fuji $\left(35^{\circ} 22^{\prime} \mathrm{N}\right.$, $138^{\circ} 46^{\prime} \mathrm{E}$ ) over two breeding seasons in 2000 and 2001 . The study area was about $800 \times$ $1,500 \mathrm{~m}$ of subalpine forest on a steep slope at $1,900-2,100 \mathrm{~m}$ asl. The forest mainly comprised conifers: Abies veitchii, Tsuga diversifolia, and Larix kaempferi, and broadleaved trees, Sorbus aucuparia and Betula ermani, with lichen-covered twigs. Understorey shrubs, Cacalia adenostyloides, covered the forest floor during the study period.

\footnotetext{
Received 20 April 2004.

* Ueda Laboratory, Department of Life Sciences, Rikkyo University, 3-34-1 Nishi-Ikebukuro, Toshima-ku, Tokyo 171-8501, Japan. E-mail: morimoto@g.nifty.jp.
} 
Observations were made over a total of 240 days (ca. 2,880 hrs) between late April and early September which covered the nesting season of both the hawk cuckoo and its main host, the Red-flanked Bushrobin. We made an effort to find as many nests as possible of the bushrobin, and other potential host species. Once a nest was found, we checked its contents regularly for cuckoo parasitism and to determine the breeding stage carefully. We searched for nests of the Olive-backed Pipit, as well as two other ground-nesting species occurring sympatrically with the hawk-cuckoo: the Arctic Warbler Phylloscopus borealis and the Wren Troglodytes troglodytes, regarded as potential hosts.

Horsfield's Hawk Cuckoos stayed and sang for about three months, early May-early August, in the study area. Two or three male hawk-cuckoos were observed to sing almost everyday. The three other large cuckoo species, Common Cuckoo Cuculus canorus, Little Cuckoo C. poliocephalus and Himalayan Cuckoo C. saturatus, were also observed occasionally in the area, but we found no evidence of breeding by these species.

During the two seasons, we found 87 nests of Red-flanked Bushrobins, nine of Arctic Warblers, ten of Wrens, and seven of Olive-backed Pipits. Of the 113 nests, only six bush robin nests and one pipit nest were parasitized by the hawk-cuckoo. No nests of Arctic Warblers and Wrens were parasitized.

The nest of the pipit was on the side of a trail at $2,040 \mathrm{~m}$ asl, and was built in the cavity of a rock, surrounded by short grass tussocks ( $50 \%$ of ground cover). It was found immediately after the start of nest building on 21 June 2001, and four days later, the female pipit laid her first egg ( $25 \mathrm{June}$ ). On the next morning, she laid the second egg, but both eggs were absent on the following morning. On the morning of 29 June, we found a fresh egg of the pipit in the nest, but by the afternoon, the egg had been removed and replaced by a strange egg. The egg was larger than that of the pipit, and the colour was pale blue (Fig. 1). The egg was depredated on the following day.

Outside Japan, the Common Cuckoo lays blue eggs in the nests of Redstarts Phoenicurus phoenicurus (Wickler 1968, Fig. 39), and the Oriental Cuckoo lays blue eggs in the nests of Long-tailed Rose Finches Uragus sibericus (Cramp 1985, pl. 96). However, these two cuckoo species with blue eggs have never been reported to breed in Japan. In Japan, the Common Cuckoo lays pale white eggs with spots and lines of variable colours and the Oriental Cuckoo egg is a shade of brown (white to light-brown or chocolate to orange-brown), but neither cuckoo ever lays blue eggs.

The blue egg found in a pipit's nest appeared to be larger than Common or Oriental Cuckoo eggs. We estimated size ranges using the mean and S.D. of eggs of the two cuckoo species in Honshu (Higuchi 1998). The estimated size ranges of Common and Oriental Cuckoo eggs, based on the rule that the mean \pm 2.58 S.D. contains $99 \%$ of the data under the assumption that the egg length distributions follow a normal distribution, are 21.3$25.48 \mathrm{~mm}$ and $17.82-21.22 \mathrm{~mm}$, respectively. The length of the blue egg $(27.6 \mathrm{~mm})$ exceeds the upper range of either species. Therefore, it is unlikely that the egg that we found is a Common Cuckoo or Oriental Cuckoo egg.

We found six parasitized bushrobin nests: one contained a hawk cuckoo nestling and the other five contained pale-blue eggs. Of the five blue eggs, two nests were lost and the other three eggs were later broken in the nests. The five blue eggs were clearly larger than 


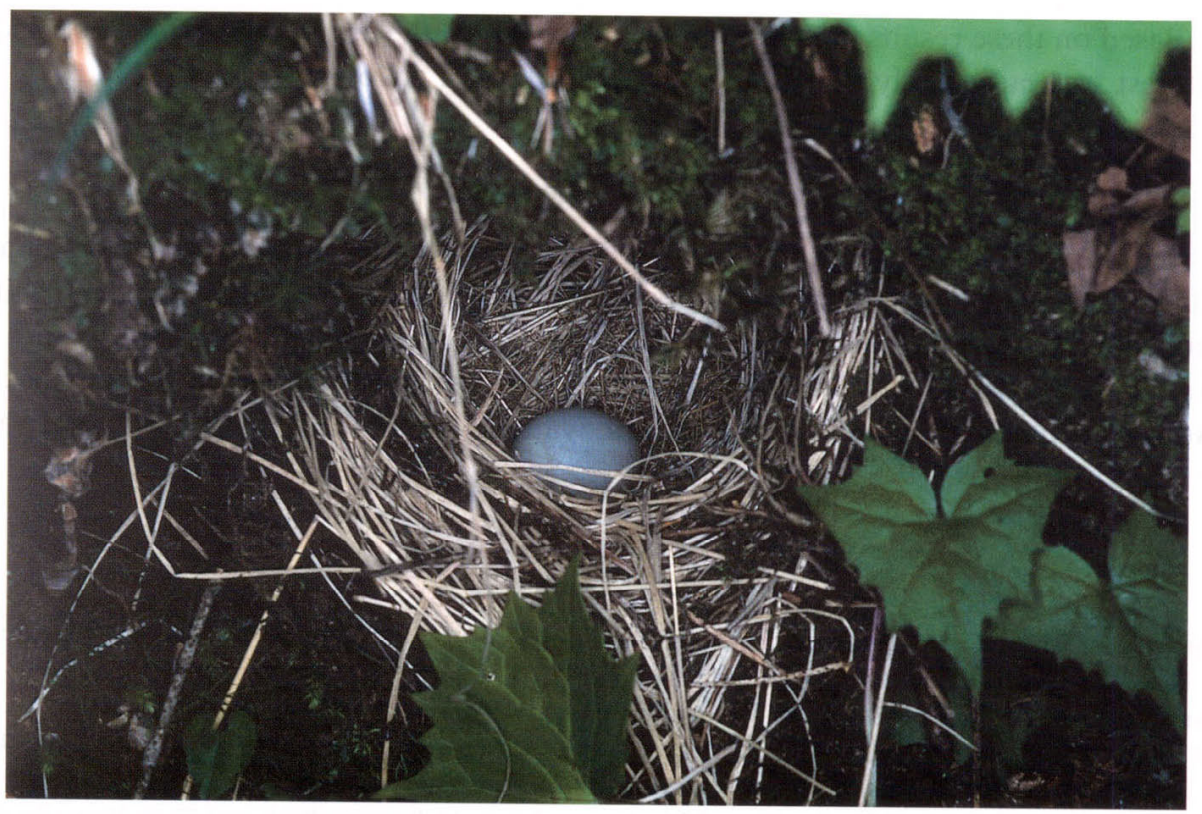

Fig. 1. An Olive-backed Pipit's Anthus hodgsoni nest with an egg of the Horsfield's Hawk-Cuckoo Cuculus fugax. The nest of the Pipit was on the side of a trail at 2,040 m asl. at Mount Fuji in Japan. The photograph of the nest was taken in 29 June when the Horsfield's Hawk-cuckoo egg was laid.

bushrobin eggs, which range from 16.5-18.2 mm in Japan (Yamashina 1941), and these five eggs were similar in size to the blue egg in the pipit's nest. We checked the skin colour of the cuckoo chicks by dissecting the three eggs mentioned above. At least two of the three chicks were identified as hawk-cuckoos, as the skin colour was dark yellowish a few days before hatching (G. Morimoto and K. Tanaka unpublished data), while the skin of Common Cuckoo chicks is blue-black and that of Little and Himalayan Cuckoos chicks is flesh-coloured (Yamashina 1941, Yoshino 1999). In addition, the gape of the hawk cuckoo chick is yellow, while it is red in chicks of the other cuckoo species (Yamashina 1941, Yoshino 1999).

No eggs typical of the Japanese populations of Common or Himalayan Cuckoos have ever been found in our study area. In areas where both cuckoo species co-occur, it is usual for each species to parasitize different hosts. For example, at Shiga Heights, in central Honshu, Midorikawa (1970) found that 30-40\% of Red-flanked Bushrobin nests were parasitized by the hawk cuckoo. Although Olive-backed Pipits bred at the same site, their nests were parasitized only by the Common Cuckoo (three of 14 pipit nests were parasitized by the Common Cuckoo; Haneda \& Hasegawa 1970). The landform of this record is similar to that of the first record of brood parasitism by Horsfield's Hawk Cuckoo on the Olive-backed Pipit in the same locality (Mount Fuji), but is at a higher elevation. 
Based on these results and circumstantial evidence, the egg found in the Olive-backed Pipit nest was most likely that of a Horsfield's Hawk Cuckoo.

\section{Acknowledgements}

We are extremely grateful to Yoshito Sudo, Yoshikazu Ushida and Takema Saitoh for their assistance during the study and also Aaron Bowman, Kentaro Takagi, Yoshitaka Narui and Hiroshi Uchida for their help in searching nests. Richard Noske and Dr. Noriyuki Yamaguchi provided critical comments on an earlier version of this manuscript. Thanks to staff of the mountain lodges Kikuya and Higashi-fuji-sansou, who supported our work in the area.

\section{References}

Committee for Check-List of Japanese Birds (ed.) 2000. Check-List of Japanese Birds: Sixth Revised Edition. The Ornithological Society of Japan, Obihiro.

Cramp, S. (ed.) 1985. The Birds of the Western Palearctic. Vol. 4. Oxford University Press, Oxford.

Haneda, K. \& Hasegawa, S. 1970. The breeding ecology of Chinese Tree-pipit. Bulletin of Institute of Nature Education in Shiga Heights 9: 23-30. (in Japanese with English summary)

Higuchi, H. 1998. Host use and egg colour of Japanese cuckoos. In Parasitic Birds and Their Hosts: Studies in Coevolution (eds. S. I. Rothstein \& S. K. Robinson), pp. 80-93. Oxford University Press, Oxford.

Kobayashi, K. 1998. The eggs of parasitic cuckoos and those of foster parents. Tori to Shizen (89): 1-15. (in Japanese)

Midorikawa, T. 1970. The Red-flanked Bushrobin. In The Natural History of Kamiminouchi-gun (ed. Committee for the history of Kamiminouchi-gun), pp. 785-792. Committee for the history of Kamiminouchi-gun, Nagano. (in Japanese)

Wickler, W. 1968. Mimicry in Plants and Animals. McGraw-Hill, New York.

Yamashina, Y. 1941. A Natural History of Japanese Birds. Iwanami-shoten, Tokyo. (in Japanese)

Yoshino, T. 1999. The Cuckoo: Japanese Brood Parasitic Birds. Bun-ichi Sougou Shuppan, Tokyo. (in Japanese) 


\section{ジュウイチによるビンズイへの托卵例}

ジュウイチによるビンズイへの托卵を確認したので報告する。日本国内で繁殖する 1 属 4 種 のカッコウ類の中でも, ジュウイチは分布がアジア圏に限られることや，その観察の困難さか ら，ほとんど研究がない。ジュウイチの主たる宿主はオオルリ，コルリ，ルリビタキであり， これらの宿主以外への托卵報告はきわめて少ない。ビンズイについても過去に富士山麓におい て 1 例の報告があるのみである。この希なビンズイへのジュウイチによる托卵を筆者らは富士 山 $\left(35^{\circ} 22^{\prime} \mathrm{N}, 138^{\circ} 46^{\prime} \mathrm{E}\right)$ の標高 $2,100 \mathrm{~m}$ の地点においてルリビタキの調査中に確認・撮影に成 功したので報告する。筆者らは調査地に抢いて 2 年間でルリビタキ 87 巣, メボソムシクイ 9 巣, ミソサザイ 10 巣, ビンズイ 7 巣を発見した。このうちジュウイチによる托卵は, ルリビタ キ 6 巣, ビンズイ 1 巣で確認された。托卵されたビンズイは造巣開始後, 産卵した。早朝観察 時の巣内にはビンズイ卵 1 卵があったが，午後に再び巣内を確認するとビンズイの卵はなく なっており, ジュウイチの卵と思われる青緑色の卵が托卵されていた。その後, この巣は捕食 されたため，それ以上の追跡はできなかった。日本国外ではジュウイチに似た青系の色の卵を 産むカッコウとッッドリが知られているが，国内での報告はない。卵の大きさはカッコウ，ッ ッドリに比ベジュウイチは大きい。発見した卵の卵長は $27.6 \mathrm{~mm}$ であり，ジュウイチ卵の大き さに近かった。これらよりこの卵はジュウイチ卵であるよ考えられた。また，この卵以外のル リビタキへの托卵 6 例（発見時：雛 1 例，卵 5 例）では，卵はルリビ夕キ卵よりも大きな青緑 色の卵であった。既に捊化していた 1 雛と破壊されていた 2 卵中の雛は, 皮膚の色からジュウ イチと確認できた。さらに, 本調査地ではジュウイチ以外のカッコウ類の托卵が見つかってい ないことも本観察がジュウイチ卵であることを支持している。

森本 元・田中啓太・上田恵介：立教大学理学部上田研究室. ₹171-8501 東京都豊島区西池 袋 3-34-1. 